\title{
Using Of garra rufa for treatment of fin rot in goldfish (Carassius auratus)
}

\section{Abstract}

Garra rufahas been used to treat fin necrosis in goldfish. Sick fish were reared in the same tank with Garra rufawhich was able to eat necrotic tissue of the fins and goldfish healed.

Keywords: Garra rufa,Goldfish, Fin rot, Fish, Flavobacterium, Gyrodactylus
Volume 3 Issue I - 2015

\author{
Calin Decebal Cojocaru, ${ }^{2}$ Clementina Luisa \\ Cojocaru' \\ 'Faculty of Animal Sciences and Biotechnology, Section of \\ Aquaculture, University of Agriculture and Veterinary Medicine \\ of Banat, Romania \\ ${ }^{2}$ Department of Aquatic Pathology Laboratory, National Sanitary \\ Veterinary and Food Safety Authority, Romania
}

Correspondence: Calin Decebal Cojocaru, Faculty of Animal Sciences and Biotechnology, Section of Aquaculture, University of Agriculture and Veterinary Medicine of Banat,Timi?oara, King Mihai I of Romania, Romania,Email c_cojocaru_d@yahoo.com

Received: October 23, 2015 | Published: October 29, 2015

\section{Introduction}

Garra rufa is a small Cyprinidae fish used to treat psoriazis in humans (www.fishbase.org) because of it is able to eat affected tissues.

\section{Aims}

Taking into account this information we tried to see if this fish can be used to treat fin rot in fish. Fin rot is a polifactorial disease, but Flavobacterium and Gyrodactylus are recognised to have the major role (Ferguson, 2006).

\section{Materials and methods}

6 naturally infected goldfish with fin rot caused by Flavobacterium sp. and Gyrodactylus sp. diagnosed by direct microscopy were introduced in an aquarium. 2 fish were separated by a glass placed inside. 6 specimens of Garra rufa were introduced with 2 separated goldfish and 4 goldfish remained isolated, without Garra rufa. ${ }^{1,2}$

\section{Results}

After 3 days, necrosis started to disappear and eroded fins started to rise because of consuming the necrotic tissues of goldfish reared in the same tank with Garra rufa. Necrosis worsened in the other 4 untreated goldfish.

\section{Conclusion}

We concluded that Garra rufa can be used to treat fin rot in warm water fish and our experiment was successful.

\section{Acknowledgments}

None.

\section{Conflicts of interest}

None.

\section{References}

1. Ferguson HW. Systemic Pathology of Fish: A Text and Atlas of Normal Tissues in Teleosts and their Response in Disease. J Fish Dis. 2006;30(6):381-382.

2. Fish Base. 